\title{
Prenatal diagnosis of isolated bilateral anophthalmia
}

\author{
Ana Mesquita Varejão, ${ }^{1}$ Inês Pestana ${ }^{2}$
}

${ }^{1}$ Obstetrics and Gynecology, Hospital Pedro Hispano, Matosinhos, Portugal ${ }^{2}$ Obstetrics, Hospital Pedro Hispano, Matosinhos, Portugal

\section{Correspondence to}

Dr Ana Mesquita Varejão; anabarbara.varejao@gmail.com

Accepted 28 July 2021

\section{Check for updates}

(C) BMJ Publishing Group Limited 2021. No commercial re-use. See rights and permissions. Published by BMJ.

To cite: Varejão AM,
Pestana I. BMJ Case
Rep 2021;14:e244684.
doi:10.1136/bcr-2021-
244684

\section{DESCRIPTION}

The patient is a 28 -year-old G2P1, with no relevant medical history and a non-consanguineous partner. She presented with an uncomplicated pregnancy, without known history of consumption of teratogenic drugs and a low risk first trimester combined screening for aneuploidies with normal nuchal translucency. At the 20-week fetal morphology scan, in 2D mode, an asymmetry of the eye balls was obvious, with reduced interorbital distance, the right orbit appeared small and hypoplastic and the left orbit was bigger with complete absence of lens bilateral aphakia (figure 1). The rest of the morphological examination was completely normal. TORCH screening completed at the time of diagnosis was negative and the patient had no family history of such congenital anomalies. Amniocentesis was suggested to obtain fetal karyotype but the patient refused. Fetal MRI was corroborative for these findings, also showing normal encephalic anatomy, with normal ventricular system and reassuring the presence of normal corpus callosum and cavum septum pellucidum. The rest of the fetal anatomy evaluated in the MRI was also normal. The couple decided to continue the pregnancy. At 30 weeks, 3D ultrasonography (figure 2) showed sunken eyelid appearance and hypoplastic orbits. She underwent spontaneous labour at term and delivered a $3250 \mathrm{~g}$ female new-born, with normal APGAR score. Bilateral anophthalmia was confirmed after birth, with suspected presence of a small cystic malformation located at the left inferior eyelid. Genetic testing after birth, using new generation sequencing panel for microphthalmia/anophthalmia confirmed heterozygotic autosomal recessive mutation for ALDH1A3 gene. The child has revealed normal growth and neurodevelopment so far. Echocardiography performed at 6 months was completely normal. ALDH1A3 encodes a protein (retinaldehyde dehydrogenase) involved in retinoic acid synthesis, playing an important role in eye development. ${ }^{1}$ Congenital bilateral anophthalmia is a

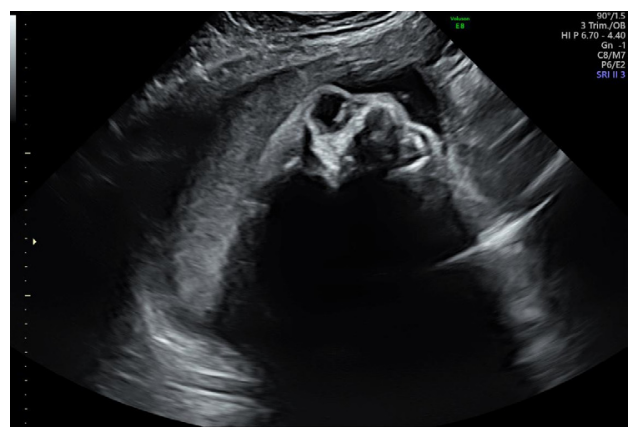

Figure $12 \mathrm{D}$ ultrasound image showing absent eyeballs at 20-week morphological examination.

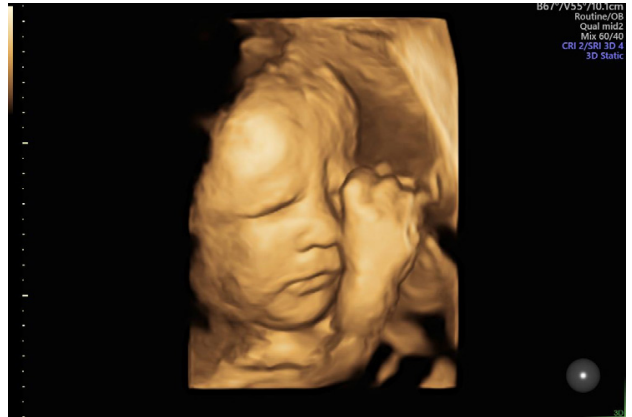

Figure 23 D ultrasound imaging showing sunken eyelid and hypoplastic orbits.

rare condition, affecting 0.6 per 10000 births, with only about $10 \%$ cases appearing isolated. Mutations in numerous genes, including RAX, PAX6, SOX2, OTX2, RARB and ALDH1A3 have been described in association with anophthalmia, being the SOX2 mutations the major single-gene mutation causing about $10 \%-15 \%$ of anophthalmia cases. Anophthalmia can also be a part of trisomy 13 (in about $1 \%$ of the cases). However, in about 50\%-60\% of the cases, no underlying genetic cause is determined. ${ }^{2}$ Prenatal diagnosis of this condition, both by $2 \mathrm{D}$ and $3 \mathrm{D}$ ultrasonography, plays a major role in providing continuation vs termination options for parents and allowing psychological preparation and planning for management of this condition, although prognosis for this fetuses is frequently uncertain. ${ }^{3}$ Although eye examination is part of routine ecoanatomy assessment, more and more 3D

\section{Learning points}

Detailed eye examination as part of morphological evaluation plays an important role in diagnosing anophthalmia. In this evaluation, 2D ultrasound may demonstrate absence of eye globe and lens on the affected side. Furthermore, 3D ultrasound may reveal valuable additional sonographic features, including sunken eyelids and small or hypoplastic orbit on the affected side and may be considered even superior to $2 \mathrm{D}$ when fetal head is deviated.

- Aphakia, the absence of the lens of the eye, should always be faced as an alarm sign for eye-balls abnormalities, since other structures located at the orbit (as cysts or haemangiomas) may mislead the evaluation and delay the diagnosis. 
imaging is considered key for early diagnosis, especially when the fetal head position is not favourable.

Contributors AMV was responsible for clinical research and elaboration of the clinical case. IP was responsible for scientific revision and approval of the final version for publication.

Funding The authors have not declared a specific grant for this research from any funding agency in the public, commercial or not-for-profit sectors.

Competing interests None declared.

Patient consent for publication Obtained.

Provenance and peer review Not commissioned; externally peer reviewed.

\section{REFERENCES}

1 Fares-Taie L, Gerber S, Chassaing N, et al. ALDH1A3 mutations cause recessive anophthalmia and microphthalmia. Am J Hum Genet 2013;92:265-70.

2 Lin S, Harlalka GV, Hameed A, et al. Novel mutations in ALDH1A3 associated with autosomal recessive anophthalmia/microphthalmia, and review of the literature. $B M C$ Med Genet 2018;19:160.

3 Searle A, Shetty P, Melov SJ, et al. Prenatal diagnosis and implications of microphthalmia and anophthalmia with a review of current ultrasound guidelines: two case reports. J Med Case Rep 2018;12:1-7.

4 Wong HS, Parker S, Tait J, et al. Antenatal diagnosis of anophthalmia by threedimensional ultrasound: a novel application of the reverse face view. Ultrasound Obstet Gynecol 2008;32:103-5.

Copyright 2021 BMJ Publishing Group. All rights reserved. For permission to reuse any of this content visit https://www.bmj.com/company/products-services/rights-and-licensing/permissions/

BMJ Case Report Fellows may re-use this article for personal use and teaching without any further permission.

Become a Fellow of BMJ Case Reports today and you can:

- Submit as many cases as you like

- Enjoy fast sympathetic peer review and rapid publication of accepted articles

- Access all the published articles

- Re-use any of the published material for personal use and teaching without further permission

\section{Customer Service}

If you have any further queries about your subscription, please contact our customer services team on +44 (0) 2071111105 or via email at support@bmj.com.

Visit casereports.bmj.com for more articles like this and to become a Fellow 